\title{
Conflicts in the Management of Crude Oil Related to the Application of Law Number 22 of 2001 Concerning Oil and Natural Gas Against People's Oil Mining in the Village of Wonocolo, Kecamatan Kedewan, Bojonegoro, East Java.
}

\author{
R. Rahaditya ${ }^{1,2, *}{ }^{*}$ Agoes Dariyo ${ }^{1}$
}

\author{
${ }^{1}$ Faculty of Law, Tarumanagara University, Jakarta, Indonesia \\ ${ }^{2}$ Faculty of Physcology, Tarumanagara University, Jakarta, Indonesia \\ *Corresponding author. Email: rahaditya@mku.untar.ac.id
}

\begin{abstract}
Research conducted in order to find out the related cases of distillation and illegal sales of crude oil mining products in the Bojonegoro area remain in Wonocolo village, Kedewan District, Bojonegoro Regency, East Java. Whereas according to the mandate of the 1945 Constitution that all natural resources should be controlled by the state and used for the prosperity and welfare of the Indonesian people. But in reality, the wealth of the archipelago is not fully able to touch and be felt by all the people, so that some of them are still classified as poor. The natural resources of our archipelago include oil and gas mining, which is managed by a state company, Pertamina. However, not all oil mining can be managed by the state, because there are still many old oil mining wells which abandoned from the era Dutch colonialism. Because of that, the oil mining was finally managed by the people. This study discusses how effective the application of Law Number 22 of 2001 concerning oil and gas mining in community oil mining in Wonocolo village, Kedewan District, Bojonegoro Regency, East Java Province. Based on the bias results, it is known that there had been a conflict involving the community of crude oil miners in Wonocolo Village with KUD Bogosasono as a partner of PT. Pertamina EP Cepu. In the case of crude oil mining (lantung) Wonocolo Village was motivated by public dissatisfaction with the transportation fee services provided by the Bogosasono Village Cooperative. Not being granted the demands of the community led to conflicts which led to illegal oil refining and selling outside official permits. Historically, the conflict began from the period of oil mining management by the Netherlands until the end of the mastery of oil management by the Cooperative Village Unit (KUD) Bogosasono and this conflict ended around 2011. Conflict resolution is carried out by way of negotiation from several parties and it results in price agreements that benefit the conflict parties. This research uses qualitative methods. Data collection techniques with interviews and observations in the field. Interviews were conducted on 10 subjects that had relevance to the life of the people's mines in Wonocolo village. The results showed the ineffectiveness of the application of Law number 22 of 2001 regarding Oil and Gas Mining in the Wonocolo deity community, Kedewan District, Bojonegoro Regency, East Java. In detail, the results of this study can be seen in the discussion section of this article.
\end{abstract}

Keywords: Law No. 22/2001, community oil mining, Wonocolo and Kedewan villages, Bojonegoro, East

Java.

\section{INTRODUCTION}

Law Number 22 Year 2001 concerning Oil and Gas Mining discusses the rules regarding oil and gas mining. The regulation focuses on oil and gas mining which is managed by an officially recognized business entity, such as Pertamina. However, in Indonesia there are still small-scale mining whose management is handled by the people, both individual and business entities, such as people's oil mining in the village of Wonocolo, Kedewan District, Bojonegoro
Regency, East Java. By the government, the existence of community oil mining is considered illegal, because its management tends not to be officially licensed.

Meanwhile, the people in Wonocolo village still have to fight hard to support themselves and their families. They have the right to a decent living. This is expressly regulated by the 1945 Constitution which states that every citizen has the right to a decent living. This means that the people run their businesses in an effort to obtain a decent living. Therefore, the people also think and act on the basis of the law which has become a law for the entire territory of the 
Republic of Indonesia. They also finally managed to manage the people's mining business in the village of Wonocolo, Kedewan District, Bojonegoro Regency, East Java Province.

The existence of people's oil mining has been going on for a long time, because the oil mine was managed by a Dutch company during the heyday of Dutch colonialism in 1898. But since the Netherlands left Indonesia, the existence of the oil mine tends to be more and more neglected. The Dutch left the oil mine because the mine was considered no longer able to produce because petroleum reserves had run out. Meanwhile, the surrounding people who live in the Wonocolo village area, Kedewan sub-district, Bojonegoro, East Java saw a good opportunity to earn a living. Finally, they do mining traditionally in old wells. Traditional mining is also known as people's oil mining.

People's Oil Mining (PMR) is a small-scale mining activity that is managed by the people. The term people mining (artisanal mining) is popular when President Ir. Soekarno issued a Presidential Decree dated July 5, 1959. The PMR characteristics include: (a) traditionally managed mining to make ends meet, (b) community mining is non-commercial mining, meaning that it is not managed for the business on a large scale, because these are managed individually, (c) mining which generally does not have official permission from the government. Because PMR is not legally licensed, PMR is considered illegal mining.

The formulation of the problem raised in this study are (1) What is the description of the people's oil mining business managed by the people in Wonocolo village, Kedewan subdistrict, Bojonegoro, East Java (2) What are the motives that encourage the people of Wonocolo village, Kedewan subdistrict, Bojonegoro, Java East to survive managing people's oil mines to cause conflict? (3) What is the view of the government and the community towards community mining in Wonocolo Village, Kedewan District, Bojonegoro Regency, East Java Province? (4) What constraints are preventing the government from enforcing Law Number 22 Year 2001 concerning Oil and Gas Mining on community oil mining in Wonocolo village, Kedewan District, Bojonegoro Regency, East Java

\section{BACKGROUND}

\subsection{The Reasons For The Miners Were Involved In Old Well Oil Mining In Wonocolo Village}

Communities carry out illegal oil mining activities, in general, are based on the urge to fulfill basic needs in their lives. People are facing economic stress, so they are trying to work according to their abilities, in order to achieve welfare. They must have an economic motive which is the motive driving someone to do a certain activity,,, in order to realize a prosperous life,. The first President of the Republic of Indonesia, Ir. Soekarno admitted that the people were in dire need of adequate food in their lives. Therefore, when the wider community knows that mining is a source of livelihood for food, it is only natural for people to flock to manage mining for their economic well-being. Because they hope to overcome the conditions of poverty in their lives.

So the economic motive is the urge of someone to carry out a certain activity which is based on the desire to fulfill their daily needs. Economic motives as the most powerful motive for a person or society in order to realize the welfare and prosperity of the community. Thus, the main reason someone is involved in mining for kerosene is economic reasons.

Wonocolo Village consists of hilly or limestone mountains. In the past, the village area of Wonocolo was an area where the land was planted with teak trees. You could say the Wonocolo village area is a shady teak forest area. However, the teak forest has produced oil. Initially, the oil mine was managed by a Dutch company. But after the Dutch left Indonesia, the oil mines were managed by the people of Wonocolo village. Now the oil mine has become the main source of livelihood for the people of Wonocolo village. So the existence of the oil mine has the impact of increasing the economy of the Wonocolo village community.

Environmental factor. The natural environment of the village of Wonocolo in the form of hills or Limestone Mountains that have the results of kerosene. The natural environment has provided natural wealth that inexhaustible produces kerosene. Kerosene mining has been going on for decades since the Dutch colonial era, 1898. Therefore, they respond to the natural environment by becoming a kerosene miner. Moreover, the environment of Wonocolo village produces more oil than other agricultural products. So the environment of the village of Wonocolo is quite unique, because this region is in the hills or Limestone Mountains, but this region produces oil.

Historical factors. The Dutch colonial government has enjoyed the triumph of the results of kerosene mining. From the results of the mine, the Netherlands was able to develop the Bojonegoro Residency area. When the Dutch lost the war with Japan, the Dutch left Indonesian territory. The Netherlands also left the old wells remaining from oil mining. Initially, the wells were scattered and not well managed. The community was moved to continue oil mining. Finally, hereditary activities for oil mining have continued to the present. According to Hardjo Nur Hadi the old well oil mine was indeed controlled and owned by the people of the village of Wonocolo, due to the existence of the traditional mining community association of the people of the village of Wonocolo and Hargomulyo, Bojonegoro since 1984.

In line with Hardjo Nur Hadi's view, it turns out that Wonocolo villagers have very impressive experiences related to the commander in chief, General Soedirman. Because General Soedirman was instrumental in establishing the existence of the Wonocolo village people's mining area. General Soedirman has issued a will known as "Legitimate Bewitz". Commander General Sudirman's will states that the people of Wonocolo receive protection to manage an oil mine to make ends meet. The main reason for the issuance of the will was the existence of the services of the Wonocolo villagers who had assisted the logistics of the army of General Soedirman's troops who were in charge of 
fighting the Dutch colonial forces. The will is kept neatly in the Wonocolo village hall.

Conflicts that have occurred related to the control of oil mining land between the mining community who feel they have a mining area that faces the management of the Village Unit Cooperative (KUD) Bogosasono as a partner of PT. Pertamina EP Cepu. The subjects of the study explained that the conflict issue that occurred in Wonocolo Village in the 2003-2008 period was related to the services provided by the Bogosasono Village Cooperative which were too cheap. Then the conflict developed in the period 2009 to 2014 in which the miners carried out illegal mining activities by refining independently and selling refined oil to outsiders other than Pertamina. The conflict resulted in material losses on Pertamina's side. Even until 2011 the mining community continued to refine independently and stop the supply of oil to Pertamina as the authorized party to process State assets in accordance with applicable laws.

In 2012, Pertamina gave permission to the Sandang Pangan Village Unit Cooperative (KUD), which has received permission to become an oil distributor from the miners to Pertamina, and managed to resolve the conflict through negotiations so that a solution was reached that the mining community would again be willing to deposit mining oil from Pertamina.

Furthermore, after successfully negotiating with the mining community, other efforts were also carried out by Pertamina in its CSR (Corporate Social Responsibility) program. In negotiating with Pertamina's miners, in addition to setting a higher price and in accordance with the wishes of the miners who want a favorable price of crude oil, they also make a business in the form of providing assistance to build a kindergarten (TK) school in 2012. Making This school is the first step to approach oil-mining residents so that they trust and are again willing to deposit lantung (crude oil) to the Sandang Pangan Cooperative as Pertamina's partner.

\subsection{The Views Of The Regional Government Regarding The Mining Of Old Well Oil}

Suyoto, Bojonegoro Regent for 2 periods (2007 - 2012, 2012 - 2017) stated that oil mining could be said to be illegal, but could also be legal. People's oil mining is considered illegal because it violates the provisions of Law Number 22 of 2001 concerning Oil and Gas Mining. This is also in line with Suprapti's view that the management of petroleum by rayat is considered illegal and needs to be resolved legally. However, this oil mine is also legal because the local government approves the existence of people who work as oil miners. They work to extract oil in order to make ends meet for their families.

Meanwhile, Mr. Jasmin, as the village head of Wonocolo acknowledged and accepted the reality of the community members who manage the people's oil mines. Many times they are called on, banned or prevented from conducting oil mining. So the government has given a ban with the threat of imprisonment and financial fines which are very burdensome for those who break them. "Every person who exploits and / or exploits without having a cooperation contract is sentenced to a maximum imprisonment of 6 (six) years and a maximum fine of Rp. 60,000 000.,000 (sixty billion rupiah)" based on the provisions of Article 52 of Law No.22 of 2001 concerning Oil and Gas. The ban was installed at various locations of oil mining locations in the village of Wonocolo. However, notice boards or prohibition boards are only limited to ineffective notice boards because they do not appear to have the power to bind the community members to obey them. They, as citizens, did not budge with the prohibition. They still carried on mining old oil wells, because they had no other choice of work.

\subsection{The Views of The community of Oil Miners}

Most of the oil miners know or acknowledge and understand the announcement board prohibition posted by the government. They understand that the prohibition is to prevent, hinder or stop the behavior of citizens so as not to mine old well oil. However, the prohibition announcement board means nothing, because the government does not provide concrete solutions related to meeting the needs of the lives of the community members. Every citizen must meet the economic needs of his family. If they do not work or are unemployed, then they do not earn, as a result the family becomes displaced.

Meanwhile, various mining wells in Wonocolo village are neglected and abandoned in such a way without anyone touching them. If the oil mining well is allowed to drag on, it means to waste opportunity after opportunity. Therefore, they must be willing to take advantage of the opportunity by reviving (utilizing) mining wells in order to produce. Now, they also continue to function old wells to be active and productive. The old wells still produce oil.

\subsubsection{Locations}

At the time of the research the mining and refining activities were still actively carried out by the Wonocolo villagers. This study takes data from the areas of Wonocolo Village and Kedewan District, Bojonegoro Regency, East Java Province. Wonocolo Village, Kedewan Subdistrict, Bojonegoro Regency is a village that consists of an old oil mining area from old wells left by the Dutch colonial government. There are approximately 1500 people in Wonocolo village. most of the Wonocolo villagers depend on the old oil fields for their wells. At present, Wonocolo village is led by Mr. Jasmin (50 years) who has served as village head since 2010 . He was unanimously elected in the village head election in 2010 and 2016. So he served as village head for the second period. 


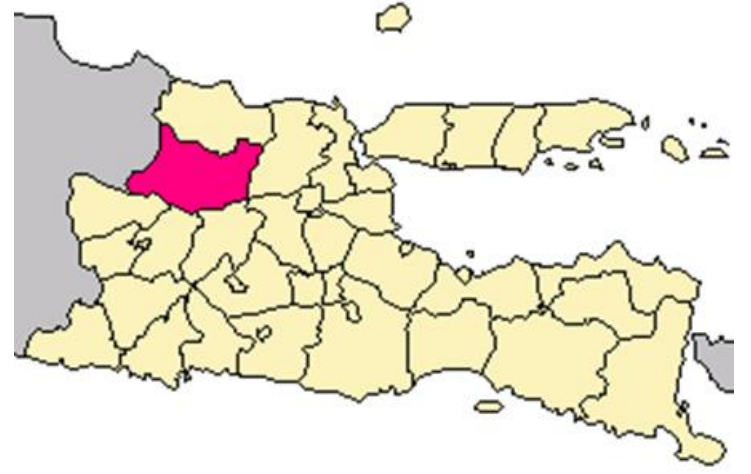

Desa Wonocolo, Kecamatan Kedewan part of Kabupaten Bojonegoro as a research location (Wikipedia, 2018)

\subsubsection{Characteristics of Research Subjects}

\begin{tabular}{|c|c|c|c|c|}
\hline 1 & $\operatorname{Jasmin}(\mathbf{J})$ & 50 & $\begin{array}{l}\text { Senior } \\
\text { High } \\
\text { School }\end{array}$ & Kepala Desa \\
\hline 2 & Aini (A) & $\begin{array}{c}197 \\
7\end{array}$ & $\begin{array}{l}\text { Senior } \\
\text { High } \\
\text { School }\end{array}$ & Guru PAUD \\
\hline 3 & $\begin{array}{l}\text { Sarwono } \\
\text { (S) }\end{array}$ & 50 & $\begin{array}{l}\text { Senior } \\
\text { High } \\
\text { School }\end{array}$ & Wiraswasta \\
\hline 4 & $\begin{array}{l}\text { Mujiharno } \\
(\mathrm{Mj})\end{array}$ & 49 & $\begin{array}{l}\text { Senior } \\
\text { High } \\
\text { School }\end{array}$ & $\begin{array}{c}\text { Karyawan } \\
\text { swasta }\end{array}$ \\
\hline 5 & Ardi (Ad) & 50 & $\begin{array}{c}\text { Senior } \\
\text { High } \\
\text { School } \\
\end{array}$ & $\begin{array}{l}\text { Pengelola } \\
\text { sumur tua }\end{array}$ \\
\hline 6 & $\begin{array}{l}\text { Sutiyono } \\
\text { (Sty) }\end{array}$ & 46 & $\begin{array}{c}\text { Bachelor } \\
\text { of Law }\end{array}$ & $\begin{array}{c}\text { Pemilik } \\
\text { sumur tua }\end{array}$ \\
\hline 7 & $\begin{array}{c}\text { Hastomo } \\
\text { Ngarbi } \\
(\mathrm{Htm})\end{array}$ & 47 & $\begin{array}{c}\text { Senior } \\
\text { High } \\
\text { School }\end{array}$ & $\begin{array}{c}\text { Kaur } \\
\text { pemerintaha } \\
\text { n desa }\end{array}$ \\
\hline 8 & $\begin{array}{l}\text { Supriyono } \\
\text { (Spy) }\end{array}$ & 50 & $\begin{array}{l}\text { Senior } \\
\text { High } \\
\text { School }\end{array}$ & $\begin{array}{c}\text { Kaur } \\
\text { perencanaan } \\
\text { desa } \\
\end{array}$ \\
\hline 9 & NN1 & 45 & $\begin{array}{l}\text { Senior } \\
\text { High } \\
\text { School }\end{array}$ & Rengkek \\
\hline $\begin{array}{l}1 \\
0\end{array}$ & NN2 & 46 & $\begin{array}{l}\text { Senior } \\
\text { High } \\
\text { School }\end{array}$ & Rengkek \\
\hline
\end{tabular}

\subsection{The Reason For Meeting The Economic Needs of rural Communities}

Legislation is indeed enforced nationally, but the legislation is apparently not effective to be applied especially in activities involving community oil mining in the village of
Wonocolo, Kedewan District, Bojonegoro Regency, East Java Province. As for the main reason that it turns out that until now the people in the area remain oil miners with the reason for the fulfillment of daily life needs.

According to the provisions of Article 52 of Law Number 22 Year 2001 states that every person who conducts exploration and / or exploitation without having a cooperation contract is sentenced to a maximum imprisonment of 6 (six) years and a maximum fine of Rp. 60,000000000 , - (six tens of billions of rupiah). This article indeed seeks to prohibit and limit the scope of movement of Wonocolo villagers not to explore oil mines in their area. However, the community is still working on oil mining since 1949 until now (2019). There is not even a sign of the community to stop or stop their mining activities, despite the existence of a statutory prohibition.

During this time, no citizen from the Wonocolo village community has been sanctioned by imprisonment just because they are mining oil in his village. There was no government action to propose Wonocolo villagers to be legally processed before a court judge. The government has never dealt with a single citizen from the area. The regulation has never been applied to the case of oil mining in the village of Wonocolo. If there is a government action to bring a legal proceeding, then all the people of Wonocolo village are ready to defend themselves and defend their entire territory in order to defend their lives.

Wonocolo villagers once made a cooperation contract with Pertamina, but the contract was terminated due to conflicts that did not resolve properly. Since the contract was terminated, the Wonocolo village community has been hesitant to enter into a cooperation contract in an effort to extract oil from old wells in their area. If they enter into a cooperation contract, they must also prepare venture capital. Meanwhile, they do not have the capital to build their business. Therefore, they also assume that they do not need to submit mining permits to the relevant authorities

\subsubsection{Regulation of Minister of Energy and Mineral Resources No. 1 of 2008.}

Minister of Energy and Mineral Resources Regulation No. 1 of 2008 concerning Guidelines for the Exploitation of Petroleum Mining in Old Wells. Minister of Energy and Mineral Resources Regulation No. 1 of 2008 must be implemented in a rooted way at the grassroots level. However, the implementation of the ESDM ministerial regulation was not in line with expectations. Wonocolo villagers continue to mine oil in old wells, with the aim of meeting the economic needs of the family.

These rules apply to the people of Wonocolo, because the area of the Wonocolo village has hundreds of old wells from the Dutch colonial heritage (435 old wells). Petroleum mining in old wells is an oil mining carried out in old wells from the Dutch colonial government. The Dutch colonial government had succeeded in managing oil well mining fields in the era of imperialism and colonialism in Indonesian territory. When the Dutch colonial government lost the war with the Japanese army and its allies, they immediately left Indonesian territory. They also left oil wells in various parts of Indonesia. Furthermore, the age of 
these old wells was neglected and not taken care of by the government of the Republic of Indonesia. One of the old wells left by the Dutch colonials is the old wells in the village area of Wonocolo

\subsubsection{Psycho-Socio-Historical-Cultural Approach.}

The people of Wonocolo village, Kedewan sub-district, Bojonegoro Regency, East Java must be understood as people who have inner and historical ties in a period of physical struggle to defend Indonesia's independence. They have a strong belief in the historical ties that have been carried out by previous generations. They have contributed greatly to assisting General Soedirman's army against the Dutch colonial invaders. On the basis of these Wonocolo community services, General Soedirman returned the favor of the Wonocolo villagers by issuing a will (legitimate bewitz). The will is believed by the mining community to guarantee and protect all Wonocolo villagers to manage the old Dutch well oil

Headings, or heads, are organizational devices that guide the reader through your paper. There are two types: component heads and text heads.

Component heads identify the different components of your paper and are not topically subordinate to each other. Examples include Acknowledgments and References and, for these, the correct style to use is "Heading 5". Use "figure caption" for your Figure captions, and "table head" for your table title. Run-in heads, such as "Abstract", will require you to apply a style (in this case, italic) in addition to the style provided by the drop down menu to differentiate the head from the text.

Text heads organize the topics on a relational, hierarchical basis. For example, the paper title is the primary text head because all subsequent material relates and elaborates on this one topic. If there are two or more sub-topics, the next level head (uppercase Roman numerals) should be used and, conversely, if there are not at least two sub-topics, then no subheads should be introduced. Styles named "Heading 1", "Heading 2", "Heading 3", and "Heading 4" are prescribed.

\subsubsection{Socio-Economic Welfare Approach}

In accordance with Article 33 of the 1945 Constitution, the government is obliged to prosper the lives of the Indonesian people. On this basis, the government must realize that the Wonocolo villagers expect to be able to achieve socioeconomic prosperity. The area of the village of Wonocolo does not have a paddy field area, but an area consisting of old wells from the former Dutch colonial oil mine. Most of Wonocolo villagers only depend their lives from the oil mining business from the Dutch colonial heritage.
If they are prohibited and are not allowed to work on the old well oil field, they will not get another livelihood. They have traditionally continued their parents 'profession in managing the old wells' petroleum mines. So from one generation to the next, inheritance is passed on to manage the old oil wells so that they are able to make ends meet. In line with the results of Yuswalina \& Candra and Alvionita's research, the mining of old well oil has a significant impact on improving the economy of the people living in the mining area. People inevitably have the motivation to increase the degree of welfare and socio-economic prosperity associated with the existence of oil mining in the region.figures and tables at the top and bottom of columns. Avoid placing them in the middle of columns. Large figures and tables may span across both columns. Figure captions should be below the figures; table heads should appear above the tables. Insert figures and tables after they are cited in the text. Use the abbreviation "Fig. 1", even at the beginning of a sentence.

\section{CONCLUSION}

Law Number 22 of 2001 concerning Oil and Gas Mining is not effective to be applied to community oil mining in the village of Wonocolo, Kedewan District, Bojonegoro Regency, East Java Province. These laws and regulations are more appropriate to be applied to large scale mining and legal entities. Meanwhile, Wonocolo village people's traditional oil mining has been carried out from generation to generation in order to provide for themselves and their families.

The ineffectiveness of the application of law number 22 of 2001 is caused by several obstacles, namely the people of Wonocolo village have strong economic needs, so they continue to mine oil in the area of old wells.

The conflict that had occurred between Wonocolo Village crude oil miners and KUD Bogosasono, which was Pertamina's partner in 2004, was related to demands for a price increase in crude oil (lantung) services which resulted in the mining community refining and selling the distillates not to Pertamina.

The conflict was only resolved in 2012 when Pertamina cooperated with the Sandang Pangan Village Unit Cooperative (KUD) to negotiate with the mining community by setting the purchase price of crude oil. The price set is equivalent to the price of diesel fuel that the community has distilled to be sold to collectors. Through price agreements produced through the negotiation process the mining community returned their mining products in the form of crude oil to Pertamina. The negotiations carried out by Pertamina in cooperation with the government to the miners through their respective village heads constituted a fairly effective conflict resolution.

It is recommended that further research be able to examine the application of customary law for the control of petroleum mining in the Wonocolo village, Kedewan 
sub-district, Bojonegoro Regency, East Java Province. During this time, there were claims between government agencies (Pertamina and Perhutani) who claimed ownership of the mining area. It could be that the next research could raise the theme of applying environmental law in the Wonocolo village area, Subdistrict, Kedewan, Bojonegoro Regency, East Java Province

\section{REFERENCES}

[1] Alvionita, R. Dampak pengelolaan minyak bumi pada sumur tua terhadap kondisi ekonomi masyarakat lokal (Studi kasus desa Wonocolo, Kecamatan Kedewan, Kabupaten Bojonegoro, Propinsi Jawa Timur). Skripsi. Jember: Fisipol Universitas Jember.(2017).

[2] Brata, N. T. Bencana (berkah) Sumur Minyak Ilegal. Tribunjateng.com. Diunduh 8 Juli 2018, pukul 22.27 wib. (2018).

[3] Côté-Lussier, C.: The Functional Relation Between Social Inequality, Criminal Stereotypes, and Public Attitudes Toward Punishment of Crime. Psychology, Public Policy, and Law, 22 (1), 46-57. (2016)

[4] Heine, S. J.. Cultural psychology. (3rd edition). New York: WW Norton \& Company. (2016).

[5] Koentjoro. Aplikasi konsep psikologi komunitas dalam pembangunan di era otonomi daerah. Jurnal psikologi Unpad, 12 (3), 35-44. (2003)

[6] Lamb, M.E.. Psycho-legal Researchers' Impact on Policies and Legal Practices: Past and Future. Psychology, Public Policy, and Law, 23 (4). 397. (2017)

[7] Maula, L. N. Tambang minyak rakyat desa Wonocolo, kecamatan kasiman, kabupaten bojonegoro tahun 1966 - 1988 ('Studi kasus sejarah sosial). Skripsi. Surabaya: Jurusan Pendidikan Sejarah Fakultas Ilmu Sosial Universitas Negeri Surabaya. (2010).

[8] Marwoto Analisis masalah dan strategi pengelolaan Sumur Tua Blok Cepu. Bogor: Sekolah Pascasarjana IPB. (2012)

[9] Munro, D Level and process in motivation and culture. Boston: McGraw-Hill. (1997).

[10] Nurmalitasari, Y. (2011). Potret kemiskinan masyarakat penambang minyak tradional. Skripsi. Yogyakarta: Fakultas Ilmu posial Universitas Negeri Yogyakarta.

[11] Panders, C.L.M. Bojonegoro 1900-1942: A Story of endemic povertyin north east java. Singapore: Gunung Agung., (1984)

[12] Perpu Nomor 37 tahun 1960 tentang Pertambangan,

[13] Peraturan Pemerintah Nomor 32 Tahun 1969 tentang pelaksanaan Undang-Undang Nomor 11 Tahun 1967 tentang Ketentuan-Ketentuan Pokok Pertambangan.

[14] Peraturan Menteri ESDM Nomor 1 Tahun 2008 tentang Pedoman Pengusahaan Pertambangan Minyak Bumi pada Sumur Tua

[15] Prijosusilo, B.). Mendayai masa depan: Rencana Indonesia untuk Kekayaan Minyaknya yang Baru. Revenew Watch Institute. (2012)

[16] Probst, T. M., Sinclair, R. R., Sears, L. E., Gailey, N. J., Black, K. J., \& Cheung, J. H. Economic Stress and Well-Being: Does
Population Health Context Matter?. Journal of Applied Population Health Context Matter?. Journal of Applied
Psychology. http://dx.doi.org/10.1037/apl0000309. (2018).

[17] Purwanto, E.A.. Mengkaji Potensi Usaha Kecil dan Menengah (UKM) untuk pembuatan Kebijakan Anti Kemiskinan di Indonesia. Jurnal Ilmu Sosial dan llmu Politik, 10 (3), 295-324. (2012)

[18] Purwanto, A. Implementasi permen esdm nomor 1 tahun 2008 di 2018 pukul 17.00 wib Diambil 23 Januari 2018 pukul $17.00 \quad \mathrm{wib}$
www.edugovindonesia.com/web/index.php/2-uncategorized. (2015).

[19] Radar Bojonegoro (2018). Sesepuh desa Wonocolo masih simpan stempel lawas bersejarah. Diunduh tanggal 18 Januari 2018.

[20] Redi, A.). Hukum penyelesaian sengketa pertambangan mineral dan batubara. Jakarta: Sinar Grafika. (2017)

[21] Rochmaningrum, FPertambangan tambang Minyak Blok Cepu dan pengaruhnya terhadap ekonomi Masyarakat desa Ledok. TAHUN 1960-2004. Yogyakarta: Nahan penambang . (2013).

[22] Siddiqoh, E.A.A. Konflik Masyarakat Penambang Minyak Mentah (Analisis Konflik Pengelolaan Pertambangan Minyak
Mentah Desa Wonocolo, Kecamatan Kedewan, Kabupaten Bojonegoro Periode 2009 - 2015). Surabaya: Fisipol Universitas Airlangga. (2016).

[23] Suprapti Penyelesaian sengketa pengelolaan sumur tua secara ditinjau dari Hukum. Jurnal Sosial Humaniora, 4 (2), 121-134. (2011).

[24] Undang-Undang Nomor 22 Tahun 2001 tentang Pertambangan Minyak dan Gas Bumi

[25] Van Ryzin, M.J., Fishbein, D \& Biglan, AThe Promise of Prevention Science for Addressing Intergenerational Poverty.
Pschology, Public Policy and Law, 24 (1), 128-143. . (2018).

[26] Yuswalina \& Candra, A. Pemanfaatan sumur minyak tua sisa eksploitasi peninggalan belanda dalam hubungannya dengan perekonomian masyarakat di kabupaten musi banyuasin. Jurna Muamalah, 3 (1), 59-72. (2010) 